\title{
THE PROTOZOAL PARASITES OF THE RAT, WITH SPECIAL REFERENCE TO THE RAT AS A NATURAL RESERVOIR OF SPIROCHATA ICTEROHAMORRHAGIA. ${ }^{1}$
}

\author{
By Alexander G. R. Foulerton, F.R.C.S., Lecturer on Public Health \\ to the London School of Medicine for Women, and in the Hygiene \\ Department of University College, London; County Medical Offeer. \\ of Health for East Sussex.
}

From the Devartment of IIygiene, University College, London, W.C. 1.

\section{(Plates II. AND III.)}

THE only natural protozoal parasite of the rat which has hitherto been studied with any attention in this country is the common Trypanosoma levisi, a parasite which apparently is harmless to its natural host, which if pathogenic at all for other rodents is so only under special conditions, and which is not known as a parasite of man. During the last four years it has been found that the rat is also a carrier of two other protozoa, Spirochata icterohomorrhagioe, Inada (Leptospira icterohomorrhagice, Noguchi), and Spirochata morsus muris, Futaki, which, whilst they, equally with the trypanosome, appear to be harmless to their natural host, are actively pathogenic under artificial conditions for certain other animals, and under natural conditions are the causes of serious infective disease in man. The rat, then, being a natural reservoir of the viruses of the diseases in man known respectively under the names of Weil's disease, Spirochotosis icterohomorrhagica, or spirochetal jaundice, and rat-bite fever, the extent to which healthy rats are infected by these parasites beconies a matter of interest.

Since the publication in English in 1916 of the original paper on Spirocheretosis icterohomorrhagica, by Inada, Ido, Hoki, Kaneko, and Ito $\left(1917^{40}\right)$, investigations in different parts of the world have shown that rat carriers of the special spirochete have a wide geographical distribution; in addition to Japanese rats, animals crught in France, in Belgium, in Spain, in the United States, in Tunis, and in Algiers have proved to be infected. The presence of the specific spirochete in rats in England not having been proved hitherto, it was decided to examine London rats, with the result that 4 carriers were found amongst 101 caught within the City and Metropolitan area. "The question of the distribution of rat carriers of Spirochota morsus muris has,

${ }^{1}$ Received May 7, 1919. 
so far as I am aware, been worked out in Japan only, but the wide geographical distribution of cases of rat-bite fever in man suggests an equally wide distribu. tion of the special rat carrier.

Considering the frequency of occurrence of these spirochetes in the rat, it might at first seem to be remarkable that their presence had been overlooked until the publication of the papers by the Japanese writers, for the rat's blood thas been examined systematically by many protozoologists in the study of the eommon trypanosomiasis of that animal. But experience has shown that in known infected animals there is the greatest difficulty in demonstrating the presence of the spirochetes in the peripheral blood by simple microscopic examination, whether of fresh blood with dark gronnd illumination, or of stained tilm specimens fixed and examined in the usial way. The only certain test is that of animal inoculation, both for detecting the presence of potentially pathogenic spirochetes and for establishing the specific identity of such as may be present. So far as the two spirochetes now under consideration are concerned, it is impossible to identify them specifically in microscopic preparation by their morphology, which varies much and is not yet fully understood.

As a matter of fact, prior to the Japanese papers, only three references to the occurrence of spirochetes in the blood of the rat have been found. In 1887, H. Vandyke Carter (1887 ${ }^{1}$ ) found, in the blood of a single rat amongst a series of 117 examined in Calcutta, an actively motile organism which he described as resembling Spirochacta obermeieri but smaller, measuring from $5 \mu$ to $9 \mu$ in length. From the fact that the spirochetes were fairly numerous in the blood, 2,3 , or 4 were present in an ordinary microscopic field, it seems to be unlikely that Carter's spirochete belonged to either of the two species referred to now. Animal inoculation experiments were inconclusive: blool from the infected rat was injected into another rat and into a Macacus monkey, whose blood was examined microscopically twice a day with negative results; but the animals appear to have been kept under observation for six days only.

In 1907, MeNoal $\left(1907^{3}\right)$ described a spirochete which he found in a rat; and in 1909, Mezineseu (1909 ${ }^{4}$ ) found a similar organism in the blood of a rat, caught at Soulina, which was also infected with trypanosomes. Mezinescu considered that his organism was of the same species as McNeal's, and gave it the name of Spirochota muris, var. galatiziana.

More recently, in 1918, Coles (1918²) examined 100 rats (Mus decumanus) caught in the town of Bournemouth and in the neighbourhood, and found thread-like bodies, which he identified with Spirochceta icterohemorrhagice in 9 of them; but, in the absence of animal inoculations, observations of this kind in connection with spirochetes cannot be accepted as being sufficient evidence of specific identity.

\section{Rat Trypanosomiasis and Trypanosoma lewisi (Kent).}

Although Trypanosoma lewisi is not known either as a parasite of man or as occurring naturally in any species other than its special host, yet a consideration of its natural history is of value in connection with the study of the other less known protozoal parasites of the rat which are actively pathogenic for man.

The frequency of infection of the rat by this trypanosome is well known. Carter $\left(1887^{6}\right)$ examined $60 \mathrm{rats}$, mostly $M$. decumanus and $M$. rathus, caught in a hotel in Bombay during the month of February, and found that 9, or 15 per cent., were carriers. Of 150 rats caught during the months of August to December, 16 , or 10 per cent., were carriers. Lingard $\left(1895^{\circ}\right)$, examining 
large numbers of rats in Bombay, found that 42 per cent. of those caught. during the rainy season (June to October) were carriers, but only 28 per cent. of those caught during the dry season (November to May) harboured the parasite. Surra is quoted by Petrie and $A$ vari as having found 35 per cent. of 3105 Bombay rats infected. Petrie and Avari (1909 13) examined 4483 rats ( $M$. rattus $2651, M$. decumanus 1832) and found that 443 per cent. of $M$. rattus and 39.5 per cent. of $M$. decumanus were carriers. These workers, in an investigation extending over fourteen months, also found evidence of a distinct seasonal prevalence of infection; from June to December the percentage of infected rats was above the mean, and from January to May the percentage was below the mean. The lowest percentages $(16.3$ for $M$. rattus and 6.5 for $M$. decumanus) were recorded in March and April, the highest (63.3 for $M$. rattus and 54.5 for $M$. decumanus) occurred in August. The season of highest prevalence of trypanosomiasis did not correspond with the period when the rats were most heavily infested with fleas. The seasonal prevalence of infestation of Bombay rats with fleas had been worked out carefully by the Plague Commission, and the two curves representing flea infestation and prevalence of trypanosomiasis amongst the rats showed completely inverse relation. Bombay rats were infested by fleas most heavily in the month of April (average 14 fleas per rat) and harboured fewest in September (4'2 fleas per rat). On the other hand, there was distinct correlation between the curves representing the atmospheric temperature and prevalence of trypanosomiasis. A rising tenperature was followed at a short interval of time by increased prevalence of infection, and a falling temperature preceded a fall in the trypanosomiasis rate. It appeared that the optimum temperature for infection by trypanosomes was about $73^{\circ} \mathrm{F}$., and Petrie and Avari suggest that possibly atmospheric humidity has an influence. They suggest also that as an atmospheric temperature of from $77^{\circ}$ to $76^{\circ} \mathrm{F}$. is necessary for the evolution of Plasmodium in the mosquito, so it may be that a certain temperature is necessary for the alleged evolution of the trypanosome in the rat flea. Jut the analogy of the respective body-temperatures of the mosquito and the rat flea cannot be pressed too closely, in view of the difference in the periodicity of their parasitic habits, and it is obvious that factors other than atmospheric temperature may be concerned with the increased prevalence of trypanosomiasis amongst Indian rats during the rainy season. Musgrave and Clegg $\left(1903^{12}\right)$ found from 20 per cent. up to 65 per cent. of rats caught in Manilla affected by trypanosomiasis, and Yakimoff and Schiller on an examination of Petrograd rats found 58 per cent. of 46 rats caught in the summer infected, and 33 per cent. of 104 rats caught in the winter. Surra having examined 3105 specimens of $M$. decumants, found 35 per cent. infected. Biot $\left(1909^{5}\right)$ in France found that $3 t$ per cent. of $M$. decumanus caught at Mâcon were infected, but only 7 per cent. of $M$. rattus; the oller rats were those mostly affected. Apparently few figures are available as to the prevalence of trypanosomiasis amongst British rats, but Strickland and Swellengrebel $\left(1910^{18}\right.$ ) found that about 25 per cent. of rats caught in and about Cambridge showed trypanosomes. Of a comparatively small number examined, 12 per cent. were described as young rats, 33 per cent. as adults, and 29 per cent. were old rats. It was noted that infection was specially prevalent in rats coming from certain localities.

In the course of the present investigation 123 rats were examined for trypanosomes, two large films each of the heart blood and of the juices of liver, kidney, and spleen being stained with Giemsa's fluid and examined. The result of the examination was that 36.6 per cent. were found to be infected. 


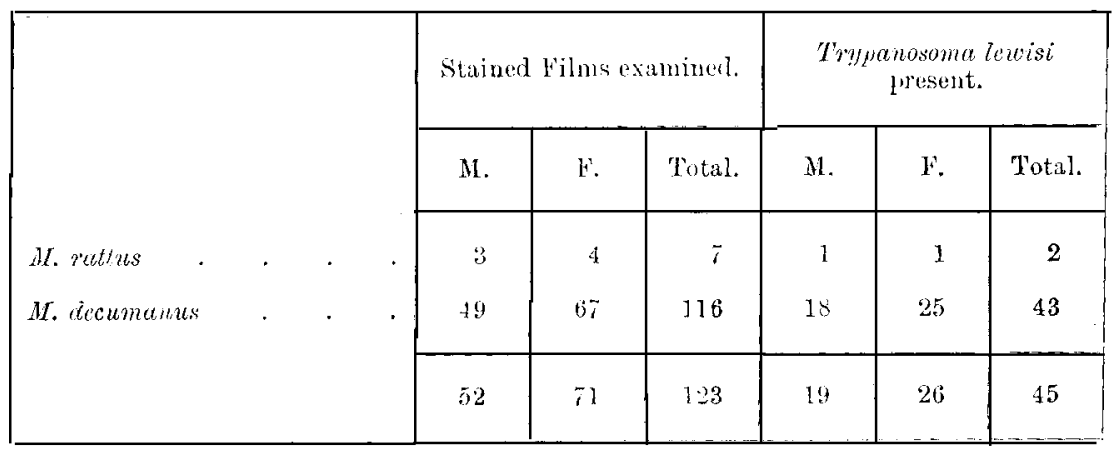

Of the 123 rats examined 107 were chassified roughly by their weight as sexually immature, young adults, fully developed adults, and old rats: :-......

\begin{tabular}{|c|c|c|c|c|c|c|}
\hline \multirow{6}{*}{ 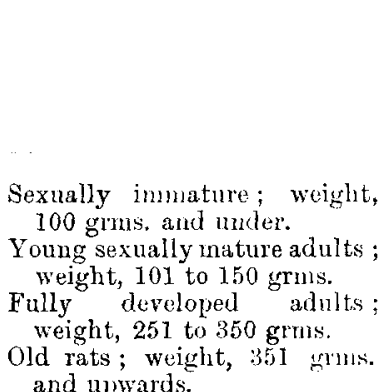 } & \multicolumn{3}{|c|}{ Stained Filnus exanined. } & \multicolumn{3}{|c|}{ Trypanosomes found. } \\
\hline & M. & F. & Total. & $M$. & F. & Total. \\
\hline & 3 & 4 & 7 & 2 & 2 & 4 \\
\hline & 29 & 39 & 68 & 11 & 14 & 25 \\
\hline & 11 & 16 & $2 \pi$ & 3 & 6 & 9 \\
\hline & 1 & 4 & 5 & 1 & 1 & 2 \\
\hline & 44 & 63 & 107 & 17 & 23 & 40 \\
\hline
\end{tabular}

Of the 123 rats examined for trypanosomes, 101 (M. rottus 3 , M. decumanus 98) were examined by guinea-pig inoculation also. Amongst the 101 so examined there were 43 ( $M$. rattus $1, M$. decumanus 42) which were carriers of $T$. lewisi. Amongst these 43 there was a single rat ( $M$. decumanus, m., 200 grms.) which was. infected with Spirochote icterohomorrhagia also. All 4 rats ( $M$. decumanus) which proved to be infected with Spirochete ieterohamorrhagioe were included amongst the 107 weighed rats; the remaining 3 specimens which did not show any trypanosomes were 2 female rats weighing 250 and 150 grms. respectively, and a male. weighing 190 grms. The consistently high percentage of infected: animals recorded by all who have investigated the prevalence of trypanosomiasis amongst rats has a bearing on the question of immunity after the termination of infection. When transmitted naturally by the rat flea, trypanosomiasis of the rat runs its course in about six weeks, and it is said commonly that the rat is immune against a fresh invasion. There is not any doubt but that the rat cannot be reinfected immediately; but the fact that some 33 . per

6 -JL. of path.--vol. xxui. 
cent. of all rats are found subject to an infection which lasts for six weeks only would sugrest that the after-period of immunity is of comparatively short duration.

\section{The T'ransmission of Tryponosoma lewisi amongst liats.}

It appears that trypanosomiasis is spreal amongst rats in several ways. Probably the commonest method for the transmission of infection from rat to rat is by the agrency of parasitic insects, the rat Hea (Ceratophyllus fusciatus) and the lat louse (Homatopinus spinulosus), of which the flea is the nore important.

The researches of Minchin and Thomson (1910 ${ }^{\prime \prime}$ ) and others indicate that Ceratophyllus acts as a true intemediate host, the trypanosome passing through a developmental phase in the flea before it is transmitted to another rat. If a batch of clean theas are fod on an infected rat and are transferred, day by day, to fresh rats, the animals which are treated with fleas taken during the first five days after the infected meal remain uninfected. Fresh rats treated with fleas taken on the sixtli, seventh, and aighth days after eommenting to feed develop a trypanosomiasis. The exiet developmental changes through which the trypanosome passes in the floa have nut been tracel ; but what are alleged to be erithidial forms of the protozom apprar in the insect's hind grat. Some six days intervene betwen the feeding of the infected flen on clean rats and thes appearance of trypanosomes in the blool of the new hout. The number of trypanosomes in the blood incseases rapidly up to about the twelfth day after their first appearance. For some tive or six weeks afterwarls the blood swarms with trypanosomes, but the actual numbers apparently do not increase after the first twelve days. After the six weeks the numbers fall away gradually, until the parasite disappears altogether'.

The conclusions of Minehin and Thomson ins to the metamorphosis of the trypanosome in the rat flea are not accepted by some observers who have doubted the specific identity of the crithidial forms seen in the insect's gut; but there is no loubt as to the fact that the flea and louse play an important part in the spreading of infection amongst rats. The exact method of dissemination of infection by these inseets is uncertain. Experimental evidence, on the whole, is against direct infection of the rat by the bite of the flea; it would appear rather to be probable that the rat becomes infected either by eating its fleas, or by the flea's excreta. Experiments by Manteufel (1909 10) and others prove that the rat can be infected by the mouth, and there is some experimental evidence also that the trypanosome is ahle to penetrate the apparently unbroken skin. Whilst, therefore, the importance of insects in sprealing infection must bo allowel, it is obvious that frequently the trypanosome may be transferred directly from rat to rat. A rat may become infected when fighting with another, or by feeding on the carcase of a recently dead infected rat. In connection with this last method of infection it may be noted that, according to Biot ( $\left.1909^{\circ}\right)$, the trypanosomes may remain alive and active for seven days after the death of the rat. The proved methods of transmission of trypanosomes from rat to rat become specially important when we come to consider the possible methods by which spirochetal infection may spread under natural conditions.

\section{The Pathogenicity of Trypanosoma lewisi.}

So far as is known, infection by the trypanosome does not affect the health of the rat, although Klein $\left(1909^{8}\right)$ described a fatal illness 
in rats associated with the presence of trypanosomes in the blood, and it has been stated that death, with enlargement of the spleen, may occur after experimental infection. Inoculation of the white rat, a variety of $M$. decumanus, is without any apparent general effect, except - that for an undetermined time after the disappearance of the trypanosomes the animal cannot be reinfected. The pathogenicity of the trypanosome for closely allied species and other rodents is very uncertain, and for a long time it was believed that the parasite could not be transferred to animals other than the rat.

Carter $\left(1887^{\circ}\right)$, however, succeeded many years ago in infecting a Macacus monkey; the trypanosomes persisted in the blood for a few days, but did not affect the animal's health. Roudsky $\left(1910^{14}, 1910^{15}\right)$ was the first to succeed in transferring infection to the white mouse. A culture of a strain of trypanosome which had been grown in Novy-McNeal medium for three weeks was passed rapidly through a series of 6 rats, subinoculations being effected carly in the infection and whilst actively multiplying forms were numerous in the blood. A white mouse inoculated from the sixth rat of the series became infected, and the strain was subsequently passed through a series of white mice. Altogether 71 per cent. of 140 mice inoculated in the peritoneum showed trypanosomes in the blood, and it was noted that an active leucocy tosis occurred in cases in which the inoculation was not followed by infection. Several of the infected mice died with appearances consistent with a protozoal disease-enlargement of the spleen and lymphatic glands, and definite changes in the liver. Roudsky (1911 ${ }^{17}$ ) succeeded in inoculating wood mice, field voles, guinea-pigs, and rabbits with what he termed his "reinforced" strain $\left\langle 1910^{16}\right)$. Subsequently Delanoe $\left(1911^{7}\right.$ ) showed that the reinforced strain was not necessary for infection of the white mouse, and that in a certain number of cases the trypanosome could be transferred directly with rat blood. Positive results were obtained with 6,4 , and 3 mice in three series of experiments in which respectively 26,10 , and 42 mice were inoculated. In other series of experiments with the passage of the trypanosome directly from mouse to monse four or tive consecutive positive results were obtained. The duration of infection in the mouse was variable, from four or five days up to a maximum of twenty-four lays, with an average period of fifteen days. Death occurred, on the third and fifth days after inoculation, in 2 out of 55 mice in which direct transference of the trypanosome was effected; in both cases the parasite was present in the blood in exceptionally large numbers and appeared to have been the cause of death. In cases in which intraperitoneal inoculation was not followed by infection, the immunity was the result of a very active phagocytosis of the parasite. Manteufel $\left(1909^{10}\right)$ found that the infectivity of the trypanosome was apparently raised after passage through adders, frogs, and lizards. The trypanosome could not be detected microscopically in the cold-blooded animal, but inoculation with their blood invariably gave positive results which, in some cases, suggested that passage through the cold-blooded animal had conferred on the parasite a certain degree of pathogenicity for the rat.

\section{Rat-bite Fever and Spirochæta morsus muris.}

For a long time past a special disease caused by rat bite has been known in Japan under the names of sokudo or sokosio, and cases of a similar illness have been described in this country, in the United States, and elsewhere as cases of rat-bite fever or rat-bite disease. The direct transmissibility of the infection was proved by Ogata (1909, 1911, 1913-14 $\left.{ }^{31}\right)$, who produced a fatal 
disease in guinea-pigs both by causing them to be bitten by apparently healthy wild rats (M. decumanus) and by inoculating them with an enulsion of the enlarged glands from cases of rat-bite fever in man. The essential features of the infection were reproduced in a second series of guinea-pigs inoculated from the first. Guinea-pigs which had been bitten by infected rats presented, in the bitten limb, a sequence of changes similar to those which had oceured in men bitten by rats, and all died within about three weeks after they had been bitten. On examination after death, the guinea-pigs, whether infected by rats or with material from human cases, showed constantly an enlargement of the lymph glands and an engorgement of the kidneys. Ogata was inclined at first to believe that the cause of rat-bite fever must be some species of protozoon, but subsequently altered his opinion and decided erroneously, as it proved, that the causative parasite was a species of Aspergillus which he had isolated from some material in the course of his investigation. It is certain that (Igata was dealing with what is now recognised as spirochetal rat-bite fever, but his conclusion as to the specific cansation of the disease was founded on al misapprehension. In 1914 a German pathologist, Schottmülier (1914 ${ }^{34}$ ), described as rat-bite fever 2 cases of illness, following respectively bites by a rat and by it South African ground squirrel, from which he isolated a streptothrix, (Streptothrix muris ratti) which he regarded as being the cause of rat-bite fever. Blake $\left(1916^{21}\right.$ ) isolated an apparently similar streptothrix from a woman who died with ulcerative endocarditis after a rat bite, and Tileston $\left(1916^{35}\right)$ recorded a case of illness after a rat bite in which he found in the blood some long thread-like and spirillary forms which were taken to be forms of the streptothrix isolated by Schottmüller and Blake. Dick and Tunnicliffe $\left(1918^{22}\right)$ also isolated an organism, Streptothrix putorii, which differed in some respects from Streptothrix muris ratti, from a case of illness which followed on the bite of a weasel, and Tunnicliffe and Mayer subsequently isolated a similar species from a case of rat-bite fever. A case of sporotrichosis, recorded by Moore and Davis $\left(1918^{29}\right.$ ) in which Sporothrix sclenclii was isolated, may be mentioned with the preceding, which have been referred to as cases of casual infection following the bites of rodents but which are clearly diflerentiated, not merely by the different parasite but also by the elinical course of the consequent disease, from the true spirochetal infection. Considering the unclean feeding habits of the rat, in particular, it is not a matter of surprise that bites of this nature should be followed by infections of various kind. Two papers by Horder (1909-10 ${ }^{25}$ ) and Atkinson (1912-13 ${ }^{20}$ ), dealing with the clinical side of what is now recognised as true rat-bite fever, were published in this cotntry whilst the exact pathology of the disease was still unknown. In 1909 Horder recorded 3 cases, and suggested the probable protozoal nature of the virus. In 1913 Atkinson, recording 6 cases, gave a full account of the disease, and emphasised in detail the probability that the infecting parasite was a protozoon. Amongst Atkinson's cases there was 1 in which the patient was bitten by a kitten which had been playing with a dead rat a short time previously. This case was a typical one of rat-bite fever, febrile paroxysms developing with regularity on every third or fourth day during the earlier stages of the infection, but being separated by rather longer intervals towards the end. Another typical case of the disease in this country, in which the patient whilst ratting was bitten by a ferret, was published by Nixon $\left(1914^{30}\right)$ in 1912. Blake (1916 ${ }^{21}$ ), whose paper includes a full bibliography of rat-bite fever up to the time of the discovery of the specific spirochete, was able to collect altogether 81 published cases; but amongst these were cases, such as his own and Schottmuiller's, which would not now be accepted as representing. the disease.

In 1916 Futaki, Takaki, Tanaguchi, and Osumi $\left(1916^{23}\right)$ published a note on 4 cases of rat-bite fever, and stated that they had identified a spirochete in the blood, skin, and lymph glands of 2 of the patients. In 1917 the same 
pathologrists published a second paper $\left({ }^{24}\right)$ recording 5 additional cases in which the same organism, which they named Spirochata morsus muris, had been found. They gave a description of the spirochete as it occurred in human disease, and recorded the finding, by dark ground illumination, of a spirochete in the blood of 1 out of 43 apparently healthy house rats (M. alexandrinus) examinel. Inoculation of a white mouse with the blood of this rat was followed by an infection identical with that produced by inoculation with material from human cases. As the results of investigation, Futaki and his colleagnes arrived at the conclusion that about 3 per cent. of house rats in Japan were carriers of Spirochceta morsus muris. The typical case of rat-bite fever caused by Spirochata morsus muris has the following characters. The bite may be followed. by some inflammation, but usually the wound apparently heals up. After an incubation period of from ten to twenty-one days, or it may be longer, the site of the wound shows a secondary inflammatory reaction, lymphingitis of the part bitten develops, and there is enlargement of the lymphatic glands. Febrile attacks recur with regularly intermittent periodicity ; and in a certain proportion of the cases a cutaneous eruption appears with, or soon after, the onset of fever, and Row $\left(1917^{32}, 1918^{33}\right)$ has recently described carefully the eruptions which developed in the course of 4 cases of rat-bite fever occtrring in India-in 2 cases on the tenth day, and in 2 cases on the fifteenth and twenty-first day respectively after the bite. These secondary skin eruptions appear on the face, trunk, and limbs and may be of a petechial or purpuric type, on papular and simulating a syphilide. The prognosis in rat-bite fever appears to be favourable; at any rate, it appears that only 3 cases of true rat-bite fever have been recorded in connection with which an opportunity for examination after death had occurred. Two of the cases, the patients being a man, xt. 71 years, and a woman, xt. 40 years, were recorded in 1917 by Kaneko and Okuda (191728), who refer also to a third case, that of a woman, et. 32 years, which was recorded by Miura and Toriyama in a Japanese medical journal in 1897 . The male patient died eighty days after he was bitten, and two women one hundred days and seventy days respectively. There were not any marked anatomical changes to be seen in any of the cases. In Kaneko and Okuda's first case the liver showed marked microscopic changes, but it does not appear to be clear as to how far these changes were caused by the spirochetal infection. In this last case spirochetes were identitied in considerable numbers in the kidneys, some were found in the suprarenal glands, and a single specimen was seen in the testicle.

With regard to exact diagnosis, Futaki and his colleagues found that demonstration of the spirochete by direct examination-in the blood, in the exudation into the skin in the neighbourhood of the healed bite, and in juice from superficial enlarged lymph glands-was difficult. Its presence could be demonstrated readily, however, by the inoculation of white mice with any of the material mentioned. The spirochete appears in the blood of the infected mouse usually about seven days, at the earliest, after direct inoculation with human material, but in some instances cannot be found in the blood until two, three, or four weeks have elapsed. The organi=ms persist in the blood for several months, and the mice usually survive. Next to the white mouse, the white rat is the most suitable animal for diagnostic inoeulation in human cases, Inoculation of guinea-pigs and monkeys with human material was found to be uncertain of result, although Ishiwara and his co-workers found subsequently that infected rat blood was pathogenic with certainty for the guinea-pig. Monkeys inoculated with human material sometimes showed an intermittent fever, but spirochetes could not be found usually in their blood. After Futaki and his colleagues had discovered the spirochete of rat-bite fever, Ishiwara, Ohtawara, and Tamura $\left(1917^{27}\right)$ investigated experimental infections produced by inoculating laboratory animals from apparently healthy rats. They confirmed Ogata's experimental infection of the guinea-pig by rat bite, and 
succeeded in transmitting the infection by scratching a guinea-pir with a rat's tooth. About 80 rats altogether were examined, of which 40 were made to bite guinea-pigs. Of the 40 biting rats only 10 (all $M$. decumanus) caused an infection. The spirochete could not be identified microscopically in the rat's mouth in any case, but spirochetes were found in the blood of one rat of the series. The course of the disease in a guinea-pig which has been infected by a bite is as follows. The limb becomes swollen, although the wound usually heals up quickly, and remains swollen until death. The skin is discoloured, and the superficial lymph glands are enlarged. There is a rise in temperature within twenty-four hours, followed soon by a fall to the normal. A second rise in temperature occurs some three to ten days later, followed again by a fall to the normal. The rise and fall in temperature may be repeated, but not with the regularity of intermission observed in human cases. The guinea-pig wastes, and dies within from two to three weeks after being bitten. The anatomical changes found after death include enlargement of the subcutaneous, axillary, ingtuinal, mesenteric, and retroperitoneal glands, enlargement and cdema of the kidneys which show subcapsular and interstitial hrmorrhages, congestion of the suprarenal glands with small hemorrhages, congestion of the liver and lungs with pneumonic foci in the latter, and sometimes a hemorrhagic exudation into the peritoneal sac. Guinea-pigs inoculated in the peritoneal sac or subcutaneous tissue with emulsions from bitten guinea-pigs always waste and die, showing on examination after death the anatomical changes just described. White rats, inoculated from guinea-pigs, show spirochetes in their blood, the spirochetes multiply, but the rats always survive. The blood of experimentally infected white rats is, equally with that of wild rats, pathogenic for the guinea-pig. The spirochetes can be transferred from white rats to white mice; of a number of white mice infected from experimental guinea-pigs, a few died, but definite anatomical changes were not found after death. A monkey (Pithecus rliesus) inoculated from an infected guinea-pig showed a rise of temperature in the third day. On the twelfth day there was a skin eruption, and the lymphatic glands were enlarged. Febrile attacks recurred every two or three days, there being six relapses in twenty-five days. Spirochetes could not be found either in the peripheral blood or in the juice of excised lymph glands, but appeared in the blood of white rats and white mice which had been inoculated with the monkey's blood.

\section{Examination of London Rats for Spirochata morsus muris.}

So far only 6 examinations of London rats for Spirochete morsus muris have been made. Each of 6 wild rats, caught during the month of January, was allowed to bite a guinea-pig in the foot. Of the 6 guinea-pigs bitten, 3 showed swelling and inflammation of the injured limb and died-1 on the third day after being bitten, 1 on the fifth day, and 1 on the fifteenth day, death in each case being caused by bacterial infections. A fourth guinea-pig died, five weeks after the bite, much wasted but without having shown any serious reaction in the injured limb; the cause of death was not ascertained in this case. The 2 remaining guinea-pigs showed only a slight. inflammatory reaction round the bite, and apparently were not otherwise affected. The results of the examination were therefore negative. 


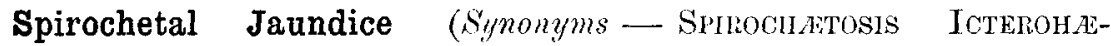 morritagica, Well's Disease, Bhlous typhord Fever, INFECTIVe JAUNDICE) AND Spirochæta icterohæmorrhagiæ.}

In 1915, Inada, Ido, Hoki, Kaneko, and Ito (42) in a joint paper deseribed a spirochete, Spirocheta icterohwmormatice, as the cause of a disease which occurs with some frequency in Japan, where it had been recognised generally as Weil's disease or febrile jumdice or, in one part of Japan, under the name of odaneti. Having discovered the eause of the disense, these writers substituted the more exact term. Spirochatosis icterohemorrhagica as a designation. The term "spirochetal jaundice" appears, however, to be sufficiently distinctive, and on the whole more convenient. Weil's disease, as described by Weil in $\mathbf{1 8 8 6}$, is a felorile illness in which a transient, but whilst it lasts often intense, juundice is a characteristic feature. The general symptoms are frequently severe, and the case-mortality of the disease in Japan is given as being about 32 per cent., a somewhat higher rate than apparently has obtained with Weil's disease elsewhere. Wril's disease has been described as occurring in most parts of the world; but judging from the number of recorded cases it does not appear that it has been at any time as common either in this country or on the Continent of lurope as it has been in Japan. Until the discovery of the specific spirochete by Inada and his colleagues, the exact diagnosis of Weil's disease nust necessarily have been a matter of some uncertainty in many cases, and consequently it is impossible to estimate the frequency of the disease in the past. It is not possible to say what proportion of the cases of illness which have been described as Weil's disease, as bilious typhoid fever, and as epidemic or infective jaundice, have been cases of the spirochetal infection, and what proportion have been cases in which a marked jaundice has been an incident in the course of some other infective disease. Possibly confusion with yellow fever, another disease in which a protozoal infection is probable, has occurred also. The discovery of Inada and his colleagues was made at an opportune time, for spirochetil jaundice appeared. with a notable sporidic prevalence amongst both allied and enemy troops during 1916. Cases of what was termed at the time "epidemic jaundice" first became noticeably prevalent anongst the British troops in France in the early summer of that year. Inada's work was not generally known at the time, but the trne nature of the disease was soon identified, and Stokes, Ryle, and Tytler $\left(1916^{60}, 1917^{\circ 1}\right)$ were the first to demonstrate the presence of Spirochata icterohwemorrhagice in cases of jaundice amongst the British. Meanwhile the disease had appeared, and had been identified, amongst both French and Belgian troops, being especially frequent amongst those serving on the front in Flanders. Bonini $\left(1917^{30}\right)$ gave an account of the disease as it had occurred on the Italian front, and especially on the Isonzo. On the German side Uhlenhuth and Fromme $\left(1917^{62}, 1916^{63}\right)$ in $1916^{6}$ had identified Inada's spirochete in cases of Weil's disease, ansfeckende gellsucht, but had substituted the name Spirccheta icterogenes for that given to the parasite by the Japanese pathologists. Amongst the Allied troops in France the disease appeared most frequently at the actual front, the rat-infested condition of the trenches affording, in the light of subsequent investigation, a sufficient explanation of its prevalence there. A considerable outbreak, described by Manine, Cristau, and Plazy (191749), which ocenred rluring the months of March, April, and May 1917, at LOrient, in Brittany, requires special mention. Originally the ontbreak was described as one of Spirocheotosis icterohemorrhagica, and the cases appear to have been of much the same clinical character as those occurring on the front. Subsequently Manine and others came to the conclusion that the spirochete in the I'Orient cases was specifically 
SUMMARY (IF RWSULTS OF EXAMINATION OF RATS

\begin{tabular}{|c|c|c|}
\hline Huferemte & Iontality: & $\begin{array}{l}\text { Mats lixaminert-Seaso } \\
\text { Year. }\end{array}$ \\
\hline 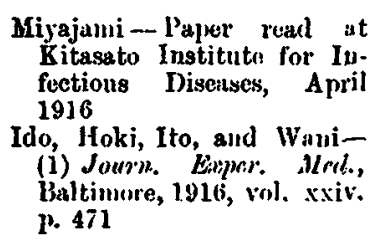 & Japan & $\begin{array}{l}\text { Rats from conl mines, and } \\
\text { house and litch rats }-86 \\
\text { examined }\end{array}$ \\
\hline $\begin{array}{l}\text { (2) Ibid., 191\%, vol. xxvi. } \\
\text { p. 341 }\end{array}$ & Jạkan & $\begin{array}{l}173 \text { rats cxamiued- } \\
\text { (a) } 149.11 . \text { decummonts } \\
\text { (b) } 24 \% \text { alexandrimus }\end{array}$ \\
\hline $\begin{array}{l}\text { Stokes, Ryle, and Tytler- } \\
\text { Lmncet, London, 1917, vol. } \\
\text { excii. p. } 142\end{array}$ & $\begin{array}{l}\text { Flanders- } \\
\text { (British Army area) }\end{array}$ & 15 tield tats \\
\hline $\begin{array}{l}\text { Martin and Pettit-Compt. } \\
\text { rend. Soc. ds Biol., Paris, } \\
1917 \text {, tome lxxx. 1. } 10\end{array}$ & $\begin{array}{l}\text { France- } \\
\text { Army are'a, Ricquetourss }\end{array}$ & 1 fiold rat \\
\hline Ilikd., 1.57. & $\begin{array}{l}\text { Fiance-- } \\
\text { (a) L'Orient } \\
\text { (b) Ronnes } \\
\text { (.) Marseilles }\end{array}$ & $\begin{array}{l}\text { (a) } 12 \text { larluour rats, May } \\
1917 \\
\text { (b) } 16 \text { iats, Mity } 1915 \\
\text { (c) } 30 \text { rith, April } 1917\end{array}$ \\
\hline 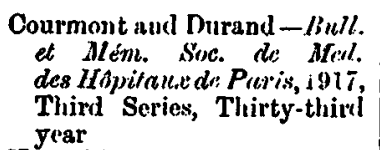 & Layon & 50 rats \\
\hline 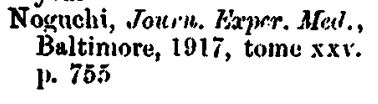 & Nיw Yurk City & $\begin{array}{l}41 \text { "wikl" rats, three } \\
\text { montlis, winter, 1916- } \\
1917\end{array}$ \\
\hline $\begin{array}{l}\text { Nicolle and Blanc, Compol. } \\
\text { rend. Soc. de Biol, Paris, } \\
\text { 1917, tome lxxx. 1. 445 }\end{array}$ & Tunis & $\begin{array}{l}119 \text { liouse rats (M. decum.- } \\
\text { anus), Feb.-March } 1917\end{array}$ \\
\hline $\begin{array}{l}\text { Nicolle and Lelailly, Aroh. } \\
\text { de l'lust. Paxteur ds, Trumis, } \\
\text { 1918, tonte x. p. 126 }\end{array}$ & T'unis & $\begin{array}{l}\text { (12 rats (.M. rlcoumcenus), De- } \\
\text { cembor } 1917- \\
\text { (a) } 8 \text { house rats } \\
\text { (b) } 21 \text { abbuttoir rats } \\
\text { (b) } 13 \text {," }\end{array}$ \\
\hline $\begin{array}{l}\text { Leger and Certain, Bull. Six. } \\
\text { ds Palh. Hitertique, 1918, } \\
\text { tome xi. p. } 19\end{array}$ & $\begin{array}{l}\text { Dakkar } \\
\text { Senegal }\end{array}$ & $\begin{array}{l}120 \text { rats, caught in sewers, } \\
\text { and about harbour during } \\
\text { winter montlis of } 1917- \\
67 \mathrm{M} \text {. alexendrinus } \\
35 \mathrm{M} \text {. raltus } \\
18 \mathrm{M} \text {. decumanns }\end{array}$ \\
\hline $\begin{array}{l}\text { Lhéritier, Bull. Sac. dis Puth. } \\
\text { Exotiquc, 1918, 1. 357 }\end{array}$ & Algiers & $\begin{array}{l}209 \text { rnts ( } M \text {. decrmanus)- } \\
\text { (a) } 109 \text { rats from sulurbs, } \\
\text { Jume-July } 1917 \\
\text { (b) } 50 \text { rats, Decomber } 1917 \\
\text { (c) } 50 \text { rats from harbour, } \\
\text { Junuary } 1918 \\
\text { lo1 rats, July - November } \\
1918 \text { - } \\
\text { (a) } 3 \mathrm{M} \text {. rattus } \\
\text { (b) } 98 \mathrm{M} \text {. decumanus }\end{array}$ \\
\hline
\end{tabular}


FROAI SPIROCIIETOSIS IUTEROHAMORRHAGICA.

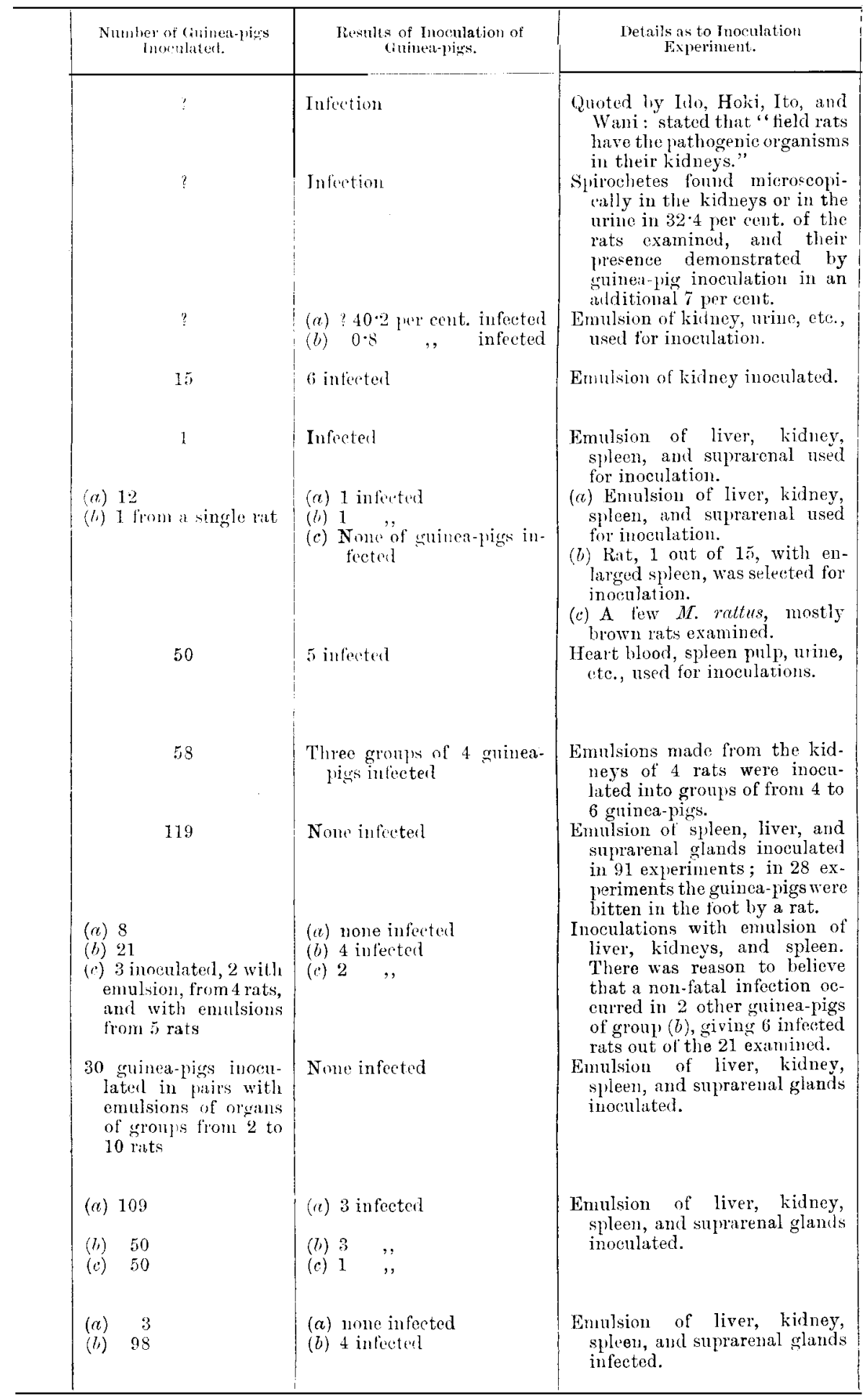


different from Inada's spirochete; but the disease was apparently the same as: that which was occurring elsewhere in France at this time.

Identification of Spirochatosis icterohemorrhagies in the healthy rat followed quickly on the discovery of its presence as the cause of spirochetal jaundice in nuan, and suggested the source of the disease which had appeared in the trenches in France and Flanders. In 1917 Ido, Hoki, Ito, and Wani $\left(1917^{40}\right)$ proved, by means of guinea-pig inoculation, the presence of the spirochete in 40.2 per cent. of 149 field rats ( $M$. decumanus) examined, and in 0.8 per cent. of 24 house rats ( $M$. alexandrinus). The same organism was found in 1 out of 6 voles (Microtus montebelli) examined by inoculation, and Miyajima is quoted as having identified it previously in the kidneys of the same species. In the same year Stokes, Ryle, and Tytler proved the vccurrence of healthy carriers of the spirochete amongst rats in the British Army area in Flanders, and Martin and Pettit $\left(1917^{50}\right)$ found the spirochete in a rat caught in a French Army area shortly afterwards. During the last two years a number of investigations have shown that carriers of the spirochete occur amongst apparently healthy rats in many parts of the world. The preceding summary of the results of various investigators, including the findings amongst London rats, indientes the wide geographical distribution of rat-carriers of the parasite of spirochetal jaundice.

\section{Frequency of Carriers of Spirochate icterohamorphagios amongst London Rats.}

Altogether 101 rats (M. rattus 3, M. decumanus 98) were specially examined for the spirochete by guinea-pig inoculation between the 12 th July and the 18th November 1918, a single guinea-pig being inoculated from each rat. The 101 rats were all included amongst. the 1.07 weighed rats as to which some details were given on p. 81, and were caught either within the City of London or in the Metropolitan area north of the Thames. The small numerical proportion of $M$. rattus is explained by the fact that the rats examined were caught in localities at some little distance from the docks and shipping; and whilst $M$. rattus rattus and $M$. rattus alexandrinus are relatively common near the riverside, they are found in but small numbers, and then only in the upper floors of warehouses and offices, in other parts of the City. No spirochete carriers were detected amongst 82 rats caught between the 12th July and the 24th October and comprised in ten batches of rats (66 in all) taken on ten different premises (warehouses, hotels, restaurants, and general offices) and two batches (8 each) of miscellaneous specimens taken from a rat-catcher's general stock. A batch of 12 rats caught at a general store on the 5 th November included 3 carriers (rats Nos. 95, 96, 98), and the last batch of 7 , caught on the 15 th November on similar premises in another part of London included at least 1 carrier. Each of the 4 guinea-pigs inoculated respectively from rats $95,96,98$, and 111 died on the twelfth day after inoculation; all presented the anatomical appearances characteristic of Spirochoetosis icterohomorthagica in the guinea-pig, and in all of them spirochetes were found on microscopic examination. The infection was transmitted in typical form to a second series 
of guinea-pigs with the virus from rats 95 and 96 ; and rat virus " 111 " has been transmitted through 25 successive series of guineapigs at the time of writing, with results which will be referred to in detail.

It is probable, however, that the 4 guinea-pigs originally infected did not represent all the spirochete carriers amongst the 101 rats. For the purposes of the present investigation, death of the guinea-pig with jaundice and the characteristic anatomical changes, together with the presence of spirochetes, were taken as the criteria of infection in the rat; but probably the test is not completely exclusive. It seems to be certain that the inoculation test, as carried out, fails in a probably small proportion of cases, either because of occasional lowered pathogenic activity of the virus, or because of exceptional resistance in individual guinea-pigs. Some evidence of this was afforded in the course of the present investigation, and an observation of Nicolle and Lebailly (1918 ${ }^{53}$ ) also suggests that the test by guineapig inoculation is not infallible. ${ }^{1}$ The percentage of infected specimens. found amongst London rats therefore must be taken as representing a number which may be slightly lower than the actual number of carriers.

\section{The Pathogenicity of Spirochceta icterohamorrhagia for Animals other than the Rat.}

In addition to the two species of rats, $M$. rattus rattus and the Alexandrine sub-species and M. decumanus, a species of field vole has been described as a natural host of the spirochete, and amongst other animals lower than man the $\log$ may be suspected as a probable occasional host.

Courmont and Durand $\left(1917^{37}\right)$, having regard to a case recorded by Krumbein and Frieling $\left(1916^{46}\right)$, in which a man apparently contracted Weil's disease from his dog, have studied the pathogenicity of the spirochete for that animal. They found that the dog could be readily infected by either intraperitoneal or subcutaneous inoculation with an emulsion of the liver of an infected guinea-pig or by feeding with small portions of the same material, showing jaundice about six days after inoculation, or about nine days after infection by the mouth. The anatomical changes found when death occurred were similar to those characteristic of the spirochetosis in the guinea-pig, and infection could be transferred back from the dog to the guinea-pig. The dog being readily susceptible to infection by the spirochete, and opportunity for direct, infection from the rat being frequent with certain classes of dogs, the causation of the attacks of jaundice to which dogs of the terrier type are liable may be suspected.

When considering rat-bite fever in man mention was made of 2

${ }^{1}$ Dalman and Balta (Compt. rend. Soe. de Biol., Puris, 1919, tome lxxxii. p. 189) found. that 13 out of 15 rats caught in Barcelona were infected. A considerable number of guineapigs were inoculated, and 17 which had received injections of known infective nuaterial s!nvived, and on inoculation twelve days after the first injection with a second dose of virus, which was fatal for fresh control guinea-pigs, proved to be immune. 
cases in which it appeared to be probable that infection might have been transmitted from the rat through a cat and through a ferret, and if the cat is susceptible to infection by Spirocheta icterohomorrhagice it is obvionsly another animal that is likely to become infected directly from the rat. In the course of the present investigation the only 2 experiments which touched the question of the pathogenicity of this spirochete for the cat were carried out with kittens of about four months of age and were, so far as they went, negative.

One kitten received an intraperitoneal injection of 1 c.c. of emulsion of the organs of a guinea-pig which represented the fifth passage of the virus from the rat, having died on the seventh day after inoculation; 2 guinea-pigs which were inoculated at the same time from the same animal died with characteristic changes on the eighth day after infection. The kitten did not show any jaundice, but becane very ill on the twelfth day after inoculation, and was chloroformed when moribund two days later. On examination after death the boly was extremely wasted, but spirochetes could not be found in the blood or tissue juices, and 2 guinea-pigs inoeulated from the organs remained in good health during four weeks afterwards. A second kitten which was fed with portions of the organs of the same grumea-pig did not show any signs of joundice, but appeared to be ill on the thirteenth day after the infected meal ; it remained obviously ill for four or five days, and then recovered. These two experiments were apparently negative, but must necessarily be repeated before being accepted as tinal. Noguchi (1918 ${ }^{5 i}$ ) states that cats are amongst the animals which, although not obviously affected by infection, are eapable of acting as carriers. A single experiment, also inconclusive, was carried ont with a blue-skinned Indian monkey, which was inoculated in traperitoneally with a mixture of the enulsions from the organs of 2 guinea-pigs which had died on the fourth and fifth days after being inoculated with virus " 111 " after its sixth passage. The monkey became ill on the fourth day after inoculation, and remained ill for several days; jaundice, however, was not observed, and the animal recovered.

A considerable number of inoculation experiments have been carried out on guinea-pigs, with results which may be epitomised as follows :-

The strains of spirochete in the 4 original carrier rats (Nos. 95, 96, 98, and 111) apperred to be of about equal virulence. One guinea-pig was inoculated from each rat, and each guinea-pig died on the twelfth day after inoculation. All subinocnlations from these guinea-pigs were carried out with emulsions made from the liver, kidney, and suprarenal gland, the mixed emulsions were made up as nearly as possible to an equal strength. In all the subinoculations after the third passage of virus " 111 " through the guinea-pig, 1 c.c. of the emulsion was injected intraperitoneally : in the earlier experiments half of that quantity was injected subcutaneously and half intraperitoneally. The subinoculations from the first series of guinea-pigs, infected from rats 95,96 , and 98 , did not give uniform results. Three guinea-pigs were inoculated from the animal infected from rat 95 , and died, all with a characteristic infection, respectively on the seventh, eighth, and eleventh days after inoculation.

of the 3 guinea-pigs inoculated with virus " 96 " at its second passage, 2 died on the ninth and eleventh days respectively with typical infection, and the third died on the forty-fourth day without having shown signs of illness except some wasting. There were not any marked anatomical changes found on examination of this last animal after death; but microscopic examination 
of the kidney juice showed spirochetes in considerable numbers, in larger numbers, in fact, than were found in any other guinea-pig examined. Two guinea-pigs which were inoculated with an emulsion of the kidneys survived, however, without showing any signs of illness.

The results of the second passage of virus " 98 " were also unequal. Of 3 guinea-pigs inoculated, 1 died on the eighth day with a characteristic infection, and the other 2 which had not shown any signs of illness were surviving eight weeks after inoculation.

Tirus " 111 " has been passed successively through 25 series of guinea-pigs, including altogether 57 animals, with the following results:-

2 guinea-pigs died, from accidental causes, within twenty-four hours of inoculation,

2 " " survived without showing any signs of illness, and

53 " " died, with a characteristic spirochetosis, within from four to twelve days after inoculation.

After the earlier passages the activity of the virus appeared to increase, with a shortening of the fatal period in most of the experiments.

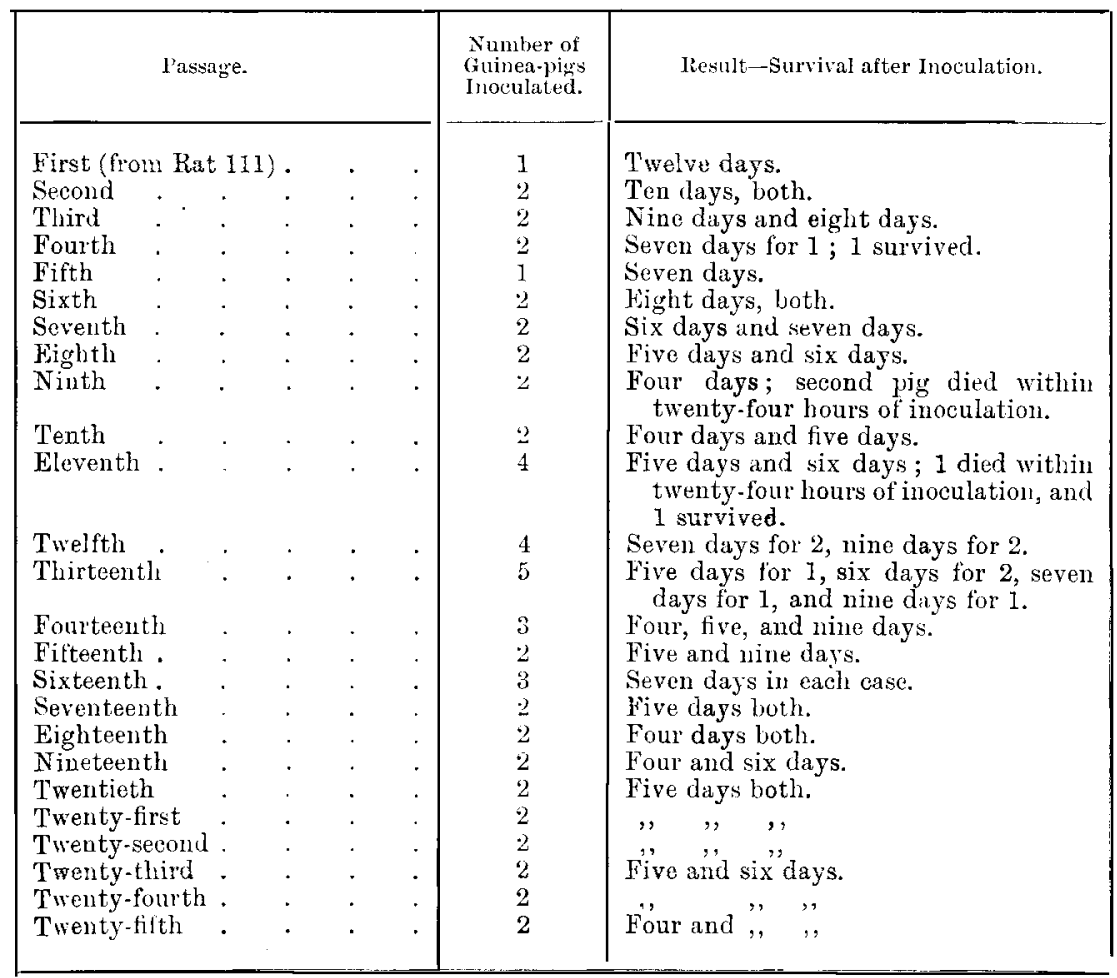

It will be noticed that of 2 guinea-pigs inoculated at the fourth passage of the virus, 1 died within the usual fatal period and 1 survived, and that at the eleventh passage 1 of the animals inoculated again survived. Neither of the 2 guinea-pigs surviving, out of 55 inoculated with virus " 111 " and not dying within twentyfour hours, showed either jaundice or any other signs of illness. As 
apparent failure to infect also occurred at the second passage with some of the guinea-pigs inoculated from rats 96 and 98 , it must be assumed that occasionally an individual guinea-pig is immune against an ordinarily fatal dose of spirochetes, and consequently in diagnostic tests more than 1 guinea-pig should be inoculated in order to reduce any chance of failure.

Well-marked gross anatomical changes were found in all of the guinea-pigs of series " 111 " which died infected, and generally all the changes were constant of occurrence.

The degree of jaundice varied; distinct yellowing of the skin was seen in almost every case, but the tint in eases which died within six days was lighter as a rule than in those dying later, and in one or two cases in which death occurred on the fourth day jaundice was not noticeable. With death on the later days the discoloration of the skin was frequently intense, and the internal organs were tinged deeply. Petechial hæmorrhages of the parietal, peritoneal, pleural, and pericardial membranes were a constant characteristic, and petechial meningeal hæmorrhages were found in 1 or 2 cases in which the brain was examined. Interstitial hemorrhages in various organs, notably in the lung, kidney, and suparenal gland, were noticeable in almost every case. In the lungs the hæmorthages appeared sometimes as small subpleural petechial lesions, sometimes as extensive hæmorrhages involving large areas (see Plate II. Fig. 1). In the case of the kidney the hæmorrhages were both subcapsular and interstitial, and usually of limited extent in the gland itself (see Plate II. Fig. 2). From the renal hæmorrhages there resulted in most cases large, bilateral, retroperitoneal collections of blood; whilst escape of blood into the bladder in the other direction was found in every case in which the urine was examined after death. Bilateral subcutaneous hæmorrhages were present in several cases, being specially noticeable in the loose tissue of the inguinal region and rather less frequent in the axillary region. In one or two cases there were extensive submucous hæmorrhages in the intestinal wall. Serous effusion, usually blool-stained, was noticeable in the peritoneal sac in most cases, and also, but on the whole less conspicuousiy, in the pericardial and pleural sacs. Usually the liver was enlarged, congested, and softened, and in many cases presented minute greyish foci on the surface and in its substance. In many animals the suprarenal glands were enlarged, engorged with blood, and softened. The condition of the spleen varied; in some of the cases the organ was obviously enlarged, in others there was not any marked naked-eye change. Enlargenent of the axillary, inguinal, lumbar, and other lymphatic glands, with or withont hremorrhage into the surrounding tissne, was found in some cases, but in other cases the glands were not obviously changed.

Material from the principal organs is under investigation at the time of writing, but this branch of the work is not yet sufficiently advanced for any generalisations to be formulated as to the general histology of the spirochetosis. The pathogenicity of virus " 111 " for the rabbit has been tested by seven experiments. Two young rabbits received intraperitoneal injections of virus " 111 " after its twelfth passage through the guinea-pig, and both died on the seventh day after inoculation, with marked jaundice and hæmorrhagic lesions; a large adult rabbit inoculated similarly with the virus after its twelfth passage was not obviously affected. Subsequently 4 rabbits, 2 being big adults and 2 young animals, were inoculated with the virus after its nineteenth passage through the guinea-pig. Of these, 1 died within twenty-four hours of inoculation, and the others survived without showing any ill effects. 


\section{Inoculation of $M$. decumanus with the Virus after repeated Passage through the Guinea-pig.}

The virulence of strain " 111 " for the guinea-pig having apparently been enhanced somewhat by its passage through that animal, it was decided to transfer the virus back to the wild rat in order to test the possibility of an acquired virulence for the natural host. Accordingly three wild rats, which had been eaged for four weeks, were inoculated at the rool of the tail with the virus after its thirteenth successive passage throngh the guinea-pig, and a fourth rat was inoculated with virus which, having been passed through 12 guinea-pigs successively, hal been passed through a rabbit and then through a thirteenth gruinca-pig. One of these died, without obvious cause, on the ninth day with spirochetes present on the urine, and the others survived. The inoculation of 4 tame rats did not produce any obvious effect.

\section{The Morphology of Spirocheta icterohamorrhayia.}

The molphology of the spirochete under various conditions has been described in detail by a number of workers, and a very careful study by Noguchi (1.918 ${ }^{56}$ ) may be mentioned specially. There is not, therefore, any need to refer to this part of the subject at length now. The living spirochetes as they were found in the course of the present investigation, seen under dark ground illumination or in stained film preparations, appeared to conform with three principal morphological types. (i.) Short, somewhat thick, "spirillum" forms showing three or four well-marked, bold curves; (ii.) struight, or nearly straight, forms with fine, closely set spirals-the Leptospira type of Noguchi: aud (iii.) longer" "thread" forms, curved at one or both ends, and resembling the type seen most frequently in fixed sections of the liver and kidney of infected guinea-pigs. When seen under dark ground illumination, the spirochete frequently is outlined by an appearance as of a highly refractile capsule. It may be, as Noguchi has suggested, that this appearance is merely an optical effect; but a corresponding unstained zono seen in stained preparations, and also brought out clearly in photographs, appears to represent a definite structural detail. Plate II. Figs. 3 and 4 are photographs of spirochetes from cultures in fresh ox-serum, and Plates II. and III. Figs. 5 to 9 represent specimens as seen in smear preparations and in sections. It may be alded that, so far as one's own observations go, the fine, closely set, spirillation of the Lephospiza type of spirochete is not a constant morphological characteristic of this species. Frequently it is not possible to detect any indication of the fine spirillation, either in living spirochetes examined under dark ground illumination or in fixed and stained preparations. Further, it is not certain that the fine spirillation, when it occurs, is a special characteristic of Spirochete ictero- 
homorhagice, and it is doubtful whether there is any constant morphological feature which ean be relied upon as a means of distinction between this organism and Spirochceta morsus muris or between either of them and other species which have been described as occurring as parasites of rodents. For the present the only satisfactory method of identification is by meaus of the animal inoculation test.

\section{Spirocheta hebdomadis and Spirochetal Seven Days' Fever.}

Spirochata hebdomadis, described recently by Ido, Ito, and Wani (1918 ${ }^{64}$, $\left.1919^{65}\right)$ as the cause of a seven days' fever, which is known in Japan under the name of Nanukayami, may be referred to here because of its aplarent relationship to Spirochata icterohamorrhagiue. It is not quite clear whether the Nanukayami of Japan is identical with the seven days' fever or dengue fever of British pathologists, the virus of which is probably conveyed by the direct agency of Culex fatigans; the Japanese disease is described as resembling clinically an atypical form of Weil's disease. The presence of the spirochete in the blood may be demonstrated in every case from the first to the fifth day of the fever, then negative results are frequent, and by the eighth day the spirochete is no longer present in the blood. Immune bodies begin to appear in the serum on the sixth and seventh days, and by the eighth day immunity is complete. The spirochete is first found in the urine about the eighth day, and afterwards in increasing numbers up to between the eighteenth and twenty-fifth days, when they are most numerous, and they may be found in the urine as late as the thirty-ninth lay. Spirochuta helsdomadis, which is differentiated serologically from Spirocheta icterohomorrhagice, is found as an apparently harmless parasite of the field vole, Microtus montebelli-mentioned previously as an occasional host of Spirocheta ieterohamorhagiee. On investigation Ido and his colleagues found that 3.3 per cent. of apparentiy healthy voles were carriers of Spirorhata heldomadis.

\section{The Transmission of Spirochata icterohemorrhagio from Rat to Liat} and the Method of Infection for Men.

Whilst it is possible, and indeed is likely, that parasitic insects may play a part in the spreading of spirochetal infection amongst rats, there is not any evidence, such as has been obtained in connection with the trausmission of Trypanosome lewisi from rat to rat by means of fleas, that such is actually the case. In the absence of exact knowledge in this matter it may be assumed that, apart from the possible conveyance of spirochetes from rat to rat by insects, infection of rat from rat may occur in one of two other ways. The infection may be direct from one animal to another, or it may be indirect through infected water, food, or soil as media for its conveyance. Opportunity for direct infection will occur when rats fight amongst each other, or feed upon infected dead rats. Indirect infection amongst rats has to be considered in relation to infection by the skin by contact of infected soil and water, and in relation to infection by the mouth through food and water. It is stated that the spirochete, like Trypanosoma lewisi, 
is able to penetrate the skin; but experimental evidence bearing on any general infection by direct penetration of the unbroken skin always requires strict scrutiny, because of obvious possibilities of fallacy. The skin is usually shaved for the purposes of the experiment, and may be abraded in the process; or the skin of the abdomen is selected for experiment with the possibility of the animal infecting. itself by licking the part, or by scratching it. However, Courmont, and Durand (1917 ${ }^{38}$ ) claim that they were able, baving eliminated all possibility of infection otherwise, to produce a typical spirochetosis in three out of six guinea-pigs experimented upon by the application of infective material to the skin. Be this as it may, the wild rat living. under natural conditions is very liable to injury of the skin, and so infection by contact of infective material is a likely occasional occurrence. In connection with the infection of food, water, and soil, there is the question of the localisation of the spirochete in the apparently healthy rat-carrier. Ido, Hoki, Ito, and Wani $\left(1917^{40}\right)$ found the spirochete only in the kidney and urine of the normal rat, and were not able to demonstrate its presence in either the liver or the blood. A wider distribution than this of the parasite in the body, however, is suggested by the fact that spirochetal jaundice in man has been caused by ratbites. In the course of the present investigation a guinen-pig was. inoculated, without any result, with 1 c.e. of blood taken from a wild rat, whose urine whilst it was still alive contained numerous spirochetes, eight days after it had been inoculated subcutaneously with an emulsion from an infected guinea-pig.

It is not quite certain whether the spirochete has been identified in the intestinal content of the healthy rat, but it has been found in the freces of infected guinea-pigs, and its presence in the freces in cases of spirochetal jaundice in man may be assumed. The presence of the spirochetes in considerable number's in the urine of rat-carriers is quite sufficient, however, to ensure a wide distribution in rat-infested areas. Very little is known as to the length of time during which the spirochete is able to maintain its vitality apart from a living host, in soil or water, but Noguchi $\left(1918^{58}\right)$ found that spirochetes from cultures in artificial media did not survive in polluted water, in soil, or in sewage for more than three days at most. In the course of the present investigation it was found by several experiments that emulsions made from the organs of guinea-pigs after the bodies had been kept in cold storage for seventy-two and ninety-six hours were fully as virulent as emulsions made immediately after death. The following experiments, also as to the infectivity of dead material were carried out.

The body of a guinea-pig, with numerous spirochetes in the liver, which had died with a typical infection nine days after inoculation, was exposed in the open air, during moderately cold weather, after the abdominal cavity had been opened up. Guinea-pigs were inoculated with emulsions made three days, five days, and eight days after death, with the results that each of the 7-JL. OF Path.-VoL. xxH11. 
animals inoculated on the third and tifth days died on the seventh day after inoculation with typical infection, whilst the last guinea-pig survived. The temperature at the time varied between $39^{\circ} \mathrm{F}$. at night and $50^{\circ} \mathrm{F}$. during the day. In several of the passages of virus " 111 " it was found that there was not any loss of virulence with material used three and four days after death of the guinea-pig. A second experiment was carried ont with an emulsion marle with ordinary tap water from the organs of another infected guinea-pig. The emulsion was exposed in the open air under exactly the same temperature conditions as those under which the body of the guinea-pig in the previous experiment had been exposed. One c.c. of the fresh emulsion killed a guinea-pig on the ninth day. A guinea-pig inoculated with the emulsion after it had stood for three days also died infected on the ninth day, whilst guineapigs inoculated after the emulsion had stood for live days and eight days survived.

Direct infection of man by the rat is of occasional occurrence, as instanced in 2 cases recorded by Ido, Hoki, Ito, and Wani $\left(1917^{40}\right)$, in which spirochetal jaundice followed rat-bites after incubation periods of six and three days respectively. Otherwise infection for man, as in the case of the rat, appears usually to be transferred indirectly, either lby food or by contact of infected water or soil with the skin. Japanese pathologists lay stress upon infection through the skin, noting the comparative prevalence of the disease amongst men who work in sewers and in certain damp coal mines; but the opportunity for skin unfection amongst miners who work bare-footed is obvious, without involving any necessity for considering the possibility of infection through unbroken skin. It has been noted also that spirochetal jaundice is specially prevalent in damp rather than in the drier coal mines, and under the former conditions the possibility of infection by contaminated food or water would be increased equally with the possibilities of infection by the skin. The possibility of infection of the rat, guinea-pig, and the $\log$ by the mouth has been proved experimentally; and on review of the evidence which is at present available it would appear to be probable that contaminated food is the most important known source of infection for spirochetal jaundice in 1nan. In making this statement the possibility of infection of man through the rat flea, or other parasitic insect, has not been taken into account, because of want at the present time of any evidence bearing directly on this. In view, however, of what is known as to the transmission of certain other protozoal infections, the existence of insect-carriers must be regarded as possible. Therefore, whilst contamination of food by the excreta of rats may be regarded as a considerable cause of the excessive prevaleuce of spirochetal jaundice amongst the troops in France and Flanders during the war, the possible influence of insects as accessory or alternative factors in spreading infection must not be lost sight of.

With regard to possibilities as to the indirect transmission of infection of man to man, whilst it would appear to be certain that the fæces are infective during the acute stage of spirochetal jaundice, the arine must be regarded as the more serious source of danger. 
Spirochetes are present in the urine during convalescence, and for as long as five or six weeks after the appearance of jaundice. It appears that the spirochetes present in the later stages tend to lose their virulence, but Noguchi (1918 ${ }^{58}$ ) bas recorded a case in which the urine was still actively pathogenic for the guinea-pig as late as four weeks after the onset of the disease, the convalescent stage of which commences usually about the fourteenth day. Infection of drinking water by man, as well as by rats, may therefore be one of the causes of the special prevalence of spirochetal jaundice amongst the workers in coal mines in Japan. According to Ido, Hoki, Ito, and Wani $\left(1917^{40}\right)$ in Japan generally spirochetal jaundice occurs but rarely at the height of the summer and during the coldest weeks of the winter, but is prevalent mostly at the end of the spring, in the early summer, and especially in the autumn. In the coal mines, where the temperature is nearly even throughout the year, there is not any special seasonal prevalence. In connection with the question of seasonal prevalence of spirochetal jaundice in man it may be noted that there are reasons for believing that infection of rats by Spirochoeta icterohomorshagice is, like infection by Trypanosoma lewisi, subject to seasonal variation. Thus Nicolle and Blanc (1917 ${ }^{52}$ ) failed to find a single infected animal amongst 119 rats caught in Tunis during the months of February and March 1917, whereas Nicolle and Lebailly (1918 ${ }^{53}$ ) found at least 6 carriers amongst 34 rats caught in December of the same year. The results of the examination of London rats also suggest, so far as they go, some seasonal prevalence of infection. Not a single carrier was detected amongst 82 rats caught between the 12 th July and the 24th October, whilst 19 rats caught between the 6 th and 13 th November included 4 carriers.

\section{REFERENCES.}

GENERAL.

1. CARIER, H. VANDYKE . " Note on the Occurrence of a Minute Bloodspirillum in an Indian Rat," Scientific Memoirs by Med. Officers of the Army of India, 1887, Part 3, p. 45.

2. Coles, A. C. . . . . "A Note on the Occurrence of Spirochata icterohamorrhagice in the Common Rat in England," Lancet, London, 1918, vol. exciv. p. 468.

3. MeNfal . . . . . "A Spirochete found in the Blood of a Wild Rat," Proc. Soc. Exper. Biol. and Merl., 1907, vol. iv. p. 125.

4. Iezinescu, D. . . . " "Sur un spirillose du rat (Note preliminaire)," Compt. rend. Soc. de Biol., Paris, 1909, . tome Ixvi. p. 158.

5. Bior . . . . . . "Au sujet de Trypanosoma lewisi," Compt. rend. Acad. d. sc., Paris, 1909, tome cxlix. p. 799 . 
6. Carter, H. Vandyke. . "On a lately demonstrated Blood-contamination and Infective Disease of Rats and of Equines in India," Seientific Memoirs by Med. Officers of the Army of India, 1887, Part 3, p. 49.

7. Delanöe, P. . . . . . "Sur la réceptivité de la souris au Trypanosoma lewisi," Compt. rend. Soc. de Biol., Paris, 1911, tome lxx. p. 649.

8. KleiN, E. . . . . . "Report on Mortality amongst Ships' Rats due to Trypanosomata," "Thivty-Nintle Annual Report of the Local Government Board, 1909-1910, p. 557.

9. Lingard, A. . . . . . "A Summary of further Report on Surra," Bombay, 1895.

10. Manteufel . . . . "Studien uber die Trypanosomiasis der Ratten mit Beriicksichtigung der Übertragung unter natürlichen Verhältnissen und der Immunitat," Arb. aus dem Kaiserl. Gesundheitsamte, 1909, Bd. xxxiii. S. 46.

11. Mrnchin, E. A., and "The Transmission of Trypanosoma lewisi by Thomson, J. D. the Rat Flea (Ceratophyllus fasciatus,)" Proc. Roy. Soc. London, 1910, Series B, vol. lxxxii. p. 273.

12. Musgrave, W. E., and "Trypanosomes and Trypanosomiasis," ReCleGG, W. T. port of Bureau of Government Laboratories, No. 5, Biological Laboratory, Manilla, 1903.

13. Petrie, G. F., and Avari, C. R.

"On the Seasonal Prevalence of Trypanosoma. lexis $i$ in $M$. rattus and $M$. decumanus and its Relation to the Mechanism of Transmission of Infection," Parasitology, 1909, vol. ii. p. 305.

14. Roudsky, D. . . . . . "Sur l'inoculation de cultures de Trypanosoma lerwisi Kent au rat blanc et sur la. réceptivité de la souris blanche à ce trypanosome," Compt. rend. Soc. de Biol., Paris, 1910, tome lxviii. p. 421.

15. ," . . . . "Sur la réceptivité de la souris blanche à. Trypanosoma levisi Kent," ilid., 1910, tome lxviii. p. 458.

15. ", . . . . "Sur le Trypanosoma levisi Kent renforcé," ibid., 1910, tome lxix. p. 384.

17. " . . . . . "Sur la possibilite de rendre le Tiypanosoma lewisi virulent pour d'autres rongeurs que le rat," Compt. rend. Acad. d. Sc., Paris, 1911, tome clii. p. 56.

18. Strickland, C., ANd Swel- "Notes on Trypanosoma levisi and its ReLENGREBEL, N. H. lation to certain Arthropoda," Parasitology, 1910 , vol. iii. p. 436 .

19. Wendelstadt AND FelL- “linwirkung von Kaltblüterpassagen auf MER. Nagana and Lewisi-Trypanosomen, Mit-. teilung," Ztschr.f. Inmunitätsforsch., 1910, Bd. v. S. 337 .

SPIROCHATA MORSUS MURIS AND RAT-BITE FEVER.

20. Atkinson, A. G. . . . "Rat-bite Fever," Med. Chron., Manchester, 1912-13, vol. lvii. p. 1. 
21. BIAKE, F. G.

22. Dick, G. F., and TunviCLIFFE, R.

23. Futaki, I., Takaki, F, Taniguchi, T., and Ostyi, $\mathrm{S}$.

24. Fu'taki, I., Takaki, F., Taniguchi, T., and Osumi, S.

25. HoRder, T. J.

26. Ido, Y., Iтo, H., WANI, H., AND OKUda, K.

27. Ishiwara, K., Ohtawara, T., and Tamura, K.

28. Kaneko, R., and Okuda, K.

29. Moore, J. J., and Davis, D. J.

30. Nixon, J. H.

31. OGATA.

32. Row, R.

33.

34. SChotrü̈LLER

35. Tileston, $W$.
"The Etiology of Rat-bite Fever," Journ. Exper. Med., Baltimore, 1916, vol. xxiii. p. 39.

"A Streptothrix isolated from the Blood of a Patient bitten by a Weasel (Streptothrix putorii)," Journ. Infect. Diseases, Chicago, 1918, vol. xxiii. p. 183.

"The Cause of Rat-bite Fever," Journ. Exper. Med., Baltimore, 1916, vol. xxiii. p. 249.

"Spirochcta morsus muris, N. sp., the Cause of Rat-bite Fever," ibid., 1917, vol. xxv. p. 33.

"Rat-bite Fever," Quart. Journ. Med., 1909-10, vol. iii. p. 121.

"Circulating Immunity Principles in Rat-bite Fever," Journ. Exper. Med., Baltimore, 1917, vol. xxvi. p. 377.

"Experimental Rat-bite Fever," Journ. Exper. Med., Baltimore, 1917, vol. xxv. p. 45.

"A Contribution to the Etiology and Pathology of Rat-bite Fever, ibid., 1917, vol. xxvi. p. 363.

"Sporotrichosis following Monse-Bite with certain Immunologic Data," Journ. Infect. Diseases, Chicago, 1918, vol. xxiii. p. 252.

"Rat-bite Fever caused by a Ferret," Brit. Med. Journ., London, 1914, vol. ii. p. 629.

"Ueber die Aitiologie der Rattenbisskrankheit," Mitteil, aus der Mediz. Fakultät der Kaiserl. Univ. zü Tokyo, 1909, Bd. viii. S. 287 ; ibid., 1911, Bd. ix. S. 343 ; ibid., 1913-14, Bd. xi. S. 179.

"On a New Species of Spirochæte isolated from a Case of Rat-bite Fever in Bombay," Indian Journ. Med. Research, 1917, vol. v. p. 386.

"Cutaneous Spirochætosis produced by Ratbite in Bombay," Bull. Soc. de Path. Exotique, 1918, vol. xi. p. 188.

Dermat. Wchnschr., 1914, Bd. lviii. S. 77.

"The Atiology and Treatment of Pat-bite Fever," Journ. Am. Med. Assoc., 1916, vol. lxvi. p. 995.

\section{SPIROCHETA ICTEROHAEMORHAGIAE AND SPIROCHETAL JAUNDICE.}

36. Bovini, G. B.

37. Courmont, J., And DurAND, $P$.

38. Couruont, J., and DurAND, $P$.
"Sull' ittero infettiva da spirocheta," Gazz. degli Osp. e delle Clin., 1917, vol. xxxviii. p. 691.

"La spirochétose ictérohémorrhagique chez le chien," Compt. rend. Soc. de Biol., Paris, 1917, tome lxxx. p. 275.

"Penetration transcutanée du spirochète de l'ictère hémorrhagique," ibid., p. 377. 
39. Counmont, J., and Dur. "Le rat d'egout réservoir de virus pour la AND, $\mathrm{P}$. spirochétose ictéro-hémorrhagique," Bull.et Mem. de la Soc. Med. des Hópitaux de Paris, 1917, $3^{\text {me }}$ Ser., 33 ${ }^{\text {me }}$ Ann. p. 115.

40. Ido, Y., Нокг, R., Iто, H., AND WANI, H.

"The Rat as a Carrier of Spirochata icterohemorrhagice, the causative agent of Weil's disease (Spirochatosis icterohcemorrhagica)," Journ. Exper. Med, Baltimore, 1917, vol. xxvi. p. 341.

41. INADA, R.

"The Clinical Aspects of Spirochetosis icterohamorrhagica or Weil's Disease," itid., 1917, vol. xxvi. p. 355 .

42. InADA, R., IDo, Y., HoKI, $R$, KANEKO, R., AND ITo, $\mathrm{H}$.

43. Jobling, J. W., AND EgGstein, A. A.

"The Etiology, Mode of Infection, and Specific Therapy of Weil's Disease (Spirochetosis icterohemorrhagica)," ibid., 1916, vol. xxiii. p. 377.

"The Wild Rats of the Southern States as Carriers of Spirochata icterohcemorhagice," Med. Rec., New York, 1917, vol. xcii. p. 1096.

41. Kaneko, R., and ORuda, $\mathrm{K}$.

"The Distribution in the Human Body of spirochata icterohcemorrhagia," Journ. Exper. Mend., Baltimore, 1917, vol. xxvi. p. 325 .

45. KLose, F.

"Ein Beitr. \%. Epidemiologie de weilschen Krankheit," München. med. Wchnschr., 1917 , S. 694.

46 Krumbein, R.; and FrieLING, B.

47. Leger and Certain .

48. LhÉretier, A.

49. Manine, Cristau and PLAZX.

"Zur weilschen Krankheit," Deutsche med. Wchnsehr., Leipzig, 1916, Bd. xlii. S. 564.

"Recherche du spirochète icterohémorrhagique chez les rats de Dakar," Bull. Soc. de Path. Exotique, 1918, tome xi. p. 19.

"Premières recherches sur les spirochètes des rats d'Alger," Bull. Soc. de Path. Exrotique, 1918, tome xi. p. 357.

"La Spirochesto. icterohomormagice à L'Orient," Compt. rend. Soc. de Biol., Paris, $19 ! 7$, tome lxxx. p. 574.

50. Martin, L., and Pettit, A.

51. Martin, L., and Pettit, A.

"Presence de Spirochata icterohamorrhagice chez le surmulot de la zone des armées," itid., Paris, 1917, tome lxxx. p. 10.

"Presence de Spirochata haemorrhagice chez le surmolot de l'interieur," ilid., p. 574.

52. Nicolle, C., and Blanc, G.

"Première enquête sur l'existence, chez le rat du Tunis, des spirochètes pathogènes pour le cobaye," ibid., Paris, 1917, tome lxxx. p. 445.

53. Nicolle, C., AND LEBaILLY, C.

"Recherches sur les maladies à spirochètes du rat transmissibles au cobaye. Premier mémoire," Arch. de l'Inst. Pasteur de Tunis, 1918, tome x. p. 125.

54. Nicolle, C., ANd Le- "Nouveaux faits concernant l'étude du BAILIY, C. spirochète de l'ictère infectieux. Un procede de longue conservation du virus dans les laboratoires; l'inoculation a la souris," Compt. rend. Soc. de Biol., Paris, 1918, tome lxxxi. p. 1143. 


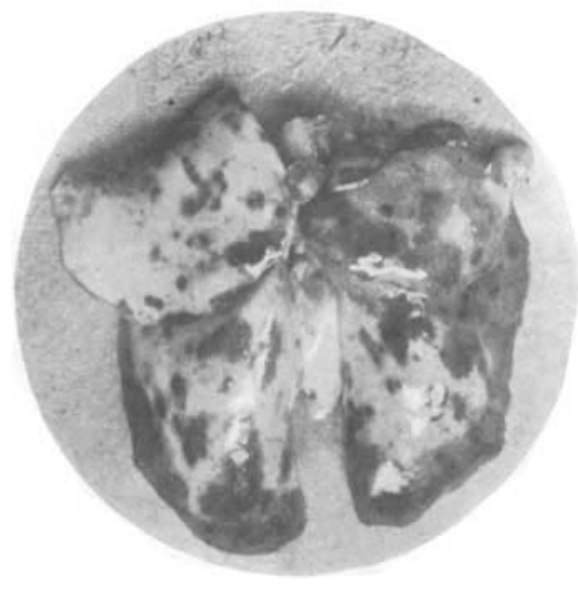

Fir. 1.

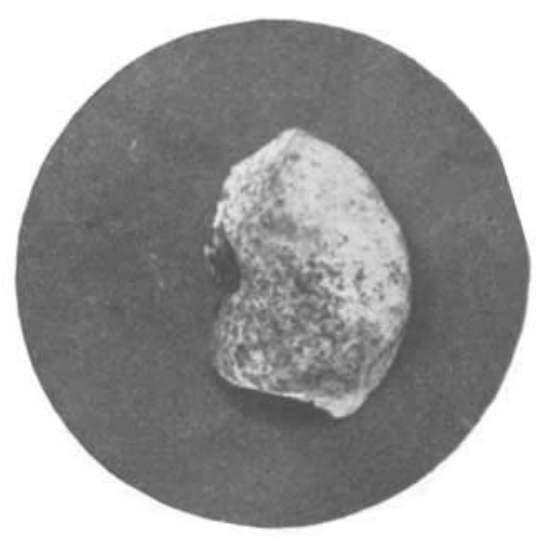

Fis. 2.

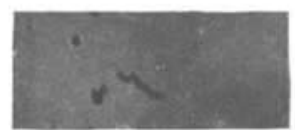

Fig, :3

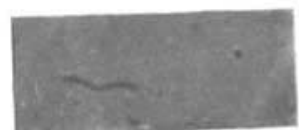

Fig. 4

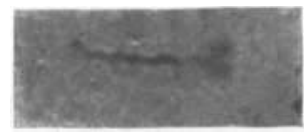

Fic. 5 


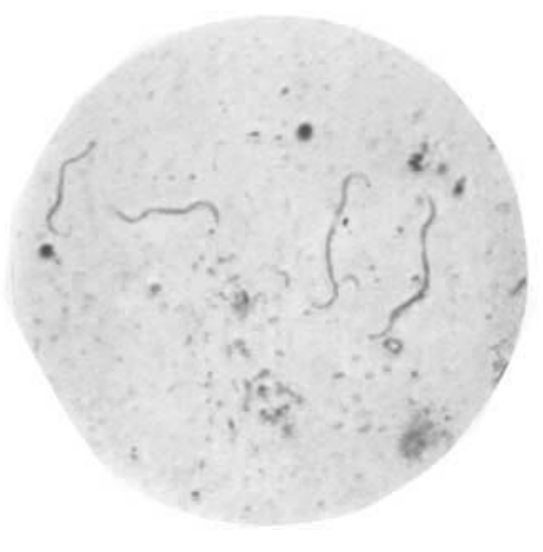

Fin, is.

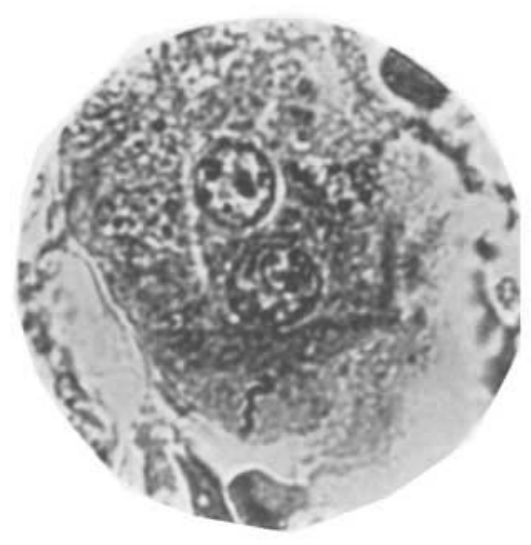

Finis.

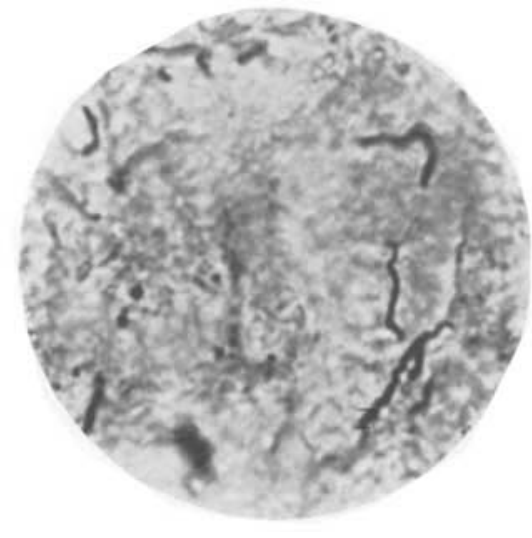

Fis. $i$.

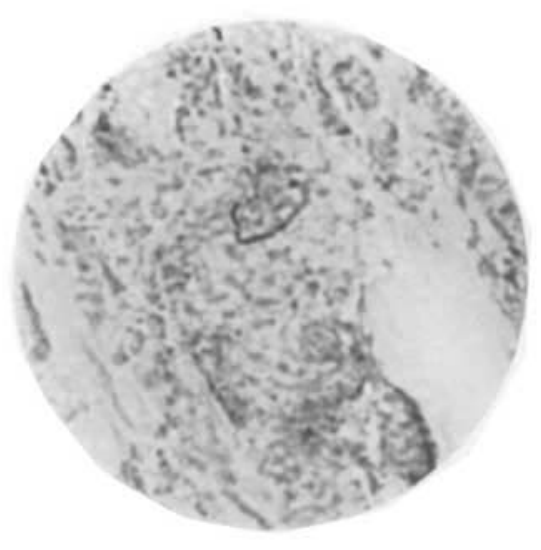

Fis, 9. 
55. Noguchi, H. . . . . . "Spirocheta ieterolecemorrhagnie in American. Wild Rats and its Relation to the Japanese and European Strains," Journ. Exper. Med., Baltimore, 1917, vol. xxv. 1). 187.

56.

"Morphological Characteristics and Nomenclature of Leptospira (Spirochceta) icterohumorrhagice. (Inada and Ido)," ibid., 1918, tome xxvii. p. 575.

57.

"Further study on the Cultural Conditions of Leptospira (Spirochceta). ieterohemorrhagice," itrid., p. 593.

58.

"The Survival of Leptoipira (Spirochuta) irteroh(s)morrhague in Nature: Observations concerning Micro-chemical Reactions and Intermedinry Hosts," ibid., p. 609.

59. SicCard, 1. 1). . . . . "Sindromi euormgiche chstrensi da spiroiheta," Gazz. deyfli Osp. e delle Clin., 1917, vol. xxxviii. p. 691.

60. Stokes, A., AND RYik, "A Note on Weil's 1)isense (Spirochetosis J. A. $\quad$ icterolucemompagies) in the British Army in Flanders," Brit. Mert. Journ., London, 1916, vol. ii. ]. 413.

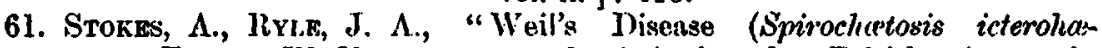
and TYTIJR, W. H. morrhagica) in the British Army in Flanders," Lancet, Jondon, 1917, vol. cxcii. p. 142.

62. UhLmnUTi . . . . "Zur Kultur der Sprirochceta icterogenes," Deutsche med. Wchnschr., Leipzig, 1917, B.l. xliii. S. 1553.

63. Uhlenhutit and Fromm: "Zur æatiologie der weilschen Krankheit," Ber. Hlin. W'clınsehr., 1916, S. 269.

\section{SPIROCH.ETA HEBDOMADIS' AND SPIROCHETAL SEVEN DAYS FEVER.}

64. IDo, Y., ITO, II., Avv "Spirochata Rebdomadis" the Causative WaNI, $H$. Agent of Seven Days' Fever (Nanukayami)," Journ. Exper. Medl., Baltimore, 1918, vol. xxviii. p. 435.

65. IDo, Y., Iro, IL., AND "Spirochata hebdomadis, the Causative Agent WANI, H.

of Seven Days'. Fever (Nanukayami)," ibid, -919 , vol. xxix. p. 199.

\section{DESCRIPTION OF PLATES II. ANI III.}

Fio. 1.-Lona prom Guin ka-pin,-Died on sixth day after inoculation with Spirochata icterohemomrleagiut.

Fis. 2, - Kinvine from Gurniga-prs. - Died on the fifth day aftor inoculation with Spirvehuta icterolkemorrhagze.

Fis. 3.-Spirochuta icterohcemonrlacusia. -Culture in fresh ox-sernum. $(\times 1000$.

Fic. 4. - Spirochata icterohamorrhagie.-Culture in fresh ox-serum. $(\times 1500$.

FrG. 5.-Spirochata ictervluemorrhuyiur.-Film of kidney jnice, stainerd with Loeffler's blue. $(\times 1500$.

FIG. 6. -Spirochathe iclerohemorrhaugice. -Film of liver jnite, stained with Giemsa's solution.

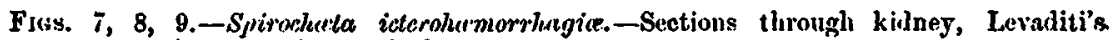
injuregination method. 